\title{
Inconsciente, intencionalidade e natureza: a dialética morganática entre naturalismo e transcendentalismo na metafísica da vontade de Schopenhauer
}

\author{
Unconscious, intentionality and nature: the morganatic dialectic between \\ naturalism and transcendentalism in Schopenhauer's metaphysics of will
}

\author{
William Mattioli \\ Doutorando em Filosofia pela UFMG e membro do GruNie (Grupo Nietzsche UFMG) \\ Email: william.mattioli@gmail.com
}

\begin{abstract}
Resumo: Tendo como inspiração a recepção do jovem Nietzsche da metafísica da vontade, as reflexões apresentadas neste trabalho acompanham, por uma perspectiva sistemática, as diversas dificuldades com as quais Schopenhauer se depara na tentativa de compatibilizar os pressupostos metafísicos de sua filosofia da natureza com o idealismo subjetivo de cunho kantiano professado por ele. O fio condutor de nossa investigação é a relação entre as noções de inconsciente, vontade, representação e natureza. Pretendemos mostrar que uma formulação consequente do naturalismo implicado em sua teoria dos graus de objetivação da vontade exige um ultrapassamento do quadro do idealismo subjetivo kantiano rumo a um idealismo objetivo. Ao fim do trabalho discutimos algumas das teses centrais de Rudolf Malter sobre o lugar do transcendentalismo no sistema schopenhauriano.
\end{abstract}

Palavras-chave: Naturalismo; Transcendentalismo; Inconsciente.

Zusammenfassung: Durch die Schopenhauer-Rezeption des frühen Nietzsche inspiriert, gehen die in dieser Arbeit dargestellten Überlegungen aus einer systematischen Perspektive den verschiedenen Schwierigkeiten nach, mit denen sich Schopenhauer konfrontiert, indem er die metaphysischen Voraussetzungen seiner Naturphilosophie mit dem subjektiven Idealismus kantischer Prägung zu vereinbaren versucht. Den Leitfaden unserer Untersuchung bildet die Beziehung zwischen den Begriffen „Unbewusstes“, „Wille“, „Vorstellung“ und „Natur“. Dadurch soll gezeigt werden, dass eine konsequente Formulierung des in seiner Theorie der Objektivationsstufen des Willens implizierten Naturalismus eine Überschreitung des kantischen subjektiven Idealismus in der Richtung eines objektiven Idealismus erfordert. Am Ende werden einige zentralen Thesen von Rudolf Malter zur Stellung des Transzendentalismus in Schopenhauers System diskutiert.

Stichwörter: Naturalismus; Transzendentalismus; Unbewusstes.

\section{Introdução}

Poucos anos após seu primeiro contato com Schopenhauer, um de seus 
discípulos de maior peso, cuja relação com o autor do Mundo é exemplar por sua honestidade, paixão e ambivalência, se debruça sobre alguns problemas presentes na teoria de seu mentor intelectual com o intuito de tornar claro para si os limites conceituais daquela metafísica voluntarista. Estamos falando aqui do jovem Friedrich Nietzsche. Nos chamados apontamentos de Leipzig, escritos entre 1867 e 1868, o jovem aspirante a filósofo se confronta, dentre outros problemas, com o que talvez seja um dos maiores paradoxos do sistema de Schopenhauer: sua tentativa de compatibilizar a teoria transcendental kantiana acerca das funções de nosso aparato cognitivo com uma narrativa naturalista de sua gênese. O cerne da crítica de Nietzsche consiste em apontar o paradoxo que há no sistema apresentado no Mundo - e que havia sido parcialmente identificado pelo próprio Schopenhauer - na medida em que a metafísica do segundo livro (assim como os complementos científicos à sua filosofia da natureza), em particular a explicação teleológica da morfologia envolvida nas manifestações da vontade, torna a epistemologia do primeiro livro inócua, se não a falsifica inteiramente. Trata-se de um problema já bastante conhecido e do qual trataremos mais exaustivamente no decorrer deste trabalho.

Vale ressaltar aqui, porém, que a crítica elaborada por Nietzsche nessas notas, como ele mesmo observa, não tinha por fim combater Schopenhauer e rebaixar sua filosofia a um sistema fadado ao fracasso por seus paradoxos internos. O que parece ter motivado o jovem filólogo e aspirante a filósofo a elaborar essa crítica era, antes, a intenção de criar uma atmosfera mais amistosa para a recepção da visão de mundo presente na metafísica da vontade ${ }^{1}$, tornando seu sistema logicamente mais consistente. Além disso, através desse exercício crítico, ele foi capaz de compreender melhor os paradoxos internos do sistema de modo a tornar os erros de Schopenhauer frutíferos, já que "os erros dos grandes homens são dignos de veneração pois são mais frutíferos que as verdades dos homens pequenos"2. O lugar e o papel que a filosofia schopenhauriana de modo geral possuía no programa filosófico do jovem Nietzsche, que será trazido à luz com a publicação de $O$ nascimento da tragédia, permaneciam intocados por essa

\footnotetext{
${ }^{1}$ Cf. LOPES, R. Ceticismo e vida contemplativa em Nietzsche, p. 141. O presente trabalho se baseia numa interpretação da filosofia de Schopenhauer inspirada na recepção do jovem Nietzsche, que tem como uma de suas influências a crítica de Rudolf Haym ao autor do Mundo. As reflexões apresentadas aqui são em grande parte devedoras das leituras de Claus Langbehn e Rogério Lopes acerca dessa problemática. ${ }^{2}$ NIETZSCHE, F. Fragmento 57[54] do outono de 1867 até a primavera de 1868, KGW I/4, p. 420.
} 
crítica mais pontual, à qual Claus Langbehn dá o nome de "crítica defensiva"3. Trata-se de uma crítica defensiva na medida em que ela pretende mostrar sob quais condições a metafísica da vontade seria passível de aceitação - isto é, após uma reforma do sistema que o tornasse consistente.

Mas se por um lado, em termos de sua motivação inicial, trata-se de uma crítica defensiva, por outro lado os resultados aos quais o jovem Nietzsche é conduzido o obrigam a rever alguns dos pressupostos básicos que moldavam a compreensão schopenhauriana da relação entre vontade, natureza, representação e consciência, pressupostos que o próprio Schopenhauer não estava disposto a abandonar. Essa revisão aponta para um ultrapassamento do quadro teórico do idealismo subjetivo kantiano ao qual Schopenhauer permanecia vinculado, o que tornaria possível a construção de um cenário conceitual no qual transcendentalismo e narrativa evolucionista seriam então compatíveis. Este é o aspecto que nos interessa em particular, na medida em que já encontramos nos meandros da própria metafísica schopenhauriana da vontade algumas indicações importantes desse ultrapassamento, sem que Schopenhauer estivesse disposto a admiti-lo integralmente. Essas indicações apontam ainda para uma sofisticação da noção de inconsciente presente em sua filosofia e, com isso, para uma teorização mais sutil da relação entre a vontade e suas manifestações.

\section{Inconsciente, vontade e representação}

Em Schopenhauer, o inconsciente aparece fundamentalmente como um predicado da vontade, através do qual esta é contraposta às atividades cognitivas conscientes do intelecto e assinalada como a força motriz de nossas ações e de todos nossos movimentos internos e externos, como um impulso cego que rege nossa vida psíquica e corporal. O termo "vontade", por sua vez, é utilizado por Schopenhauer para designar tanto a dimensão volitiva desta nossa vida psíquica e corporal, assumindo o papel de elemento mais saliente de nossa experiência num sentido inteiramente imanente, quanto a essência última de nosso ser no sentido da coisa em si kantiana. Nesse último sentido, ele designa aquela dimensão que transcende totalmente o mundo da experiência, isto é, o mundo como representação e suas formas: tempo, espaço e

\footnotetext{
${ }^{3}$ LANGBEHN, C. Metaphysik der Erfahrung. Zur Grundlegung einer Philosophie der Rechtfertigung
} beim frühen Nietzsche, p. 128. 
causalidade. Estas, enquanto formas do princípio de razão, constituem nosso modus cognoscendi, uma vez que o princípio de razão é o que determina todos os modos possíveis da relação cognitiva entre o sujeito que conhece e o objeto que é conhecido. $\mathrm{O}$ projeto de uma metafísica imanente, como o concebe o autor do Mundo, só é possível dentro desse contexto se formos capazes de acessar a coisa em si por meio de um tipo especial conhecimento que de certo modo escapa ao princípio de razão, sem com isso ultrapassar a dimensão da experiência. Esse conhecimento, Schopenhauer o encontrará na vivência imediata do corpo próprio.

Ainda no primeiro livro do Mundo, onde o mundo inteiro é considerado segundo seu aspecto representacional, o corpo já assume um papel especial na medida em que, diferentemente dos objetos externos, conhecidos mediatamente por meio da aplicação da lei de causalidade às impressões sensíveis, ele nos é conhecido de modo imediato. $\mathrm{O}$ corpo como objeto imediato é o ponto de partida da própria intuição dos objetos externos. A intuição de um objeto empírico ocorre quando o entendimento aplica o princípio de causalidade às impressões sensíveis, operação na qual o efeito sofrido diretamente no corpo é referido a uma causa projetada externamente no espaço e que é então intuída enquanto objeto. Nas palavras de Schopenhauer: "As mudanças que cada corpo animal sofre são imediatamente conhecidas, isto é, sentidas, e, na medida em que esse efeito é de imediato relacionado à sua causa, origina-se a intuição desta última

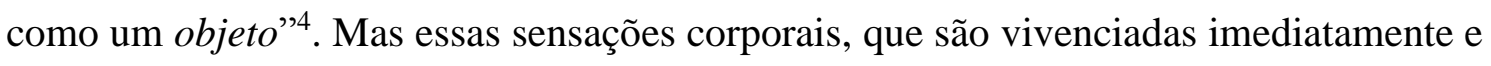
nos fazem conscientes das coisas do mundo, sendo o ponto de partida de toda intuição empírica, relacionam-se cognitivamente com o entendimento somente na medida em que afetam os sentidos de forma meramente objetiva e são tão fracas que não produzem dor ou prazer ${ }^{5}$. Nesse nível cognitivo da experiência, portanto, relacionamo-nos com nosso corpo ainda segundo seu aspecto meramente representacional. No entanto, um outro nível de experiência é alcançado quando o que está em jogo são nossas vivências de dor e prazer. Estas se relacionam diretamente com a vontade; através delas algo em nós é afetado que, segundo Schopenhauer, não pode ser reduzido à mera representação. Nesse sentido, a experiência corporal da dor e do prazer nos mostra o corpo não mais

\footnotetext{
${ }^{4}$ SCHOPENHAUER, A. WWV I/MVR I, § 4, p. 53. As traduções do primeiro volume do Mundo são de Jair Barboza (cf. bibliografia), com pequenas e eventuais modificações, e a paginação segue a edição brasileira. O restante das traduções são de nossa autoria, e a paginação segue a edição de Paul Deussen que consta em Schopenhauer im Kontext (cf. bibliografia).

${ }^{5}$ Ibid., $\S 18$, p. 158 .
} 
como mero objeto entre objetos, isto é, como representação, mas sim com relação ao seu caráter volitivo mais essencial. Isso ocorre pois estes dois sentimentos não são de forma alguma representações, "mas sim afecções imediatas da vontade em seu fenômeno, o corpo: um querer ou não-querer relativo à impressão, imperativo e imediato, que este sofre."6

Além dos sentimentos de dor e prazer, Schopenhauer acredita que podemos vir a conhecer nossa essência íntima mediante um redirecionamento do olhar àquilo que subjaz à dinâmica do nosso organismo como um todo. Para ele, o sujeito é capaz de reconhecer sua vontade como sua essência através dos movimentos que esta produz o tempo todo no seu corpo. Conquanto tais movimentos sejam vistos como resultado dos atos de uma vontade que habita esse corpo, eles não podem ser separados dos atos mesmos.

Todo ato verdadeiro de sua vontade é simultânea e inevitavelmente também um movimento de seu corpo. Ele não pode realmente querer o ato sem ao mesmo tempo perceber que este aparece como movimento corporal. $\mathrm{O}$ ato da vontade e a ação do corpo não são dois estados diferentes, conhecidos objetivamente e vinculados pelo nexo da causalidade; nem se encontram na relação de causa e efeito; mas são uma única e mesma coisa, apenas dada de duas maneiras totalmente diferentes, uma vez imediatamente e outra na intuição do entendimento. $^{7}$

$\mathrm{Na}$ filosofia de Schopenhauer, portanto, especialmente na passagem do transcendentalismo à metafísica, o corpo comparece como uma espécie de pedra de toque da relação entre fenômeno e vontade, assumindo assim um duplo estatuto: por um lado como representação, como objeto imediato do sujeito tomado em seu aspecto cognitivo; por outro, porém, como vontade, como sua objetivação mais imediata no próprio sujeito, tomado em seu aspecto volitivo. Nesse registro teórico de uma metafísica imanente, a designação da essência do corpo pelo termo "vontade" é marcada por uma equivocidade notável e fatal: Schopenhauer parte do sentido psicológico do termo, extraído da experiência que temos de nossos atos volitivos na perspectiva de primeira pessoa, operando em seguida uma transição para o nível transpessoal que pode causar vertigens num leitor mais atento. Não somos mais capazes de identificar

\footnotetext{
${ }^{6}$ Ibid.

${ }^{7}$ Ibid., p. 157. 


\section{WILLIAM MATTIOLI}

quando o filósofo está usando a palavra em sua significação psicológica e quando ele a usa no sentido metafísico, como aquela instância transcendente cuja manifestação mais imediata é o corpo em sua dinâmica e materialidade. O mesmo vale para a noção de inconsciente que acompanha sistematicamente este conceito.

Valendo-se dessa equivocidade fundamental no emprego do termo "vontade", o autor do Mundo realiza então o que talvez seja um dos passos mais temerários do seu sistema: partindo da constatação de que nossa real essência deve ser buscada no conjunto de nossa vida corporal (instintiva e afetiva), e não no elemento intelectual da nossa subjetividade como quisera a maioria dos filósofos, ele então extrapola sua análise em dois sentidos: em primeiro lugar, aquilo que foi identificado como caracterizando nossa própria essência deve agora valer para a caracterização da essência do mundo enquanto tal, passo que é dado através do argumento da analogia; em segundo lugar, ao transpor o âmbito psicológico para o metafísico, ele submete sua concepção a um dualismo profundamente problemático, isolando o pólo inconsciente da volição e remetendo a cognição ao registro secundário (ou melhor, terciário) da consciência. Com esse movimento ele estabelece um dualismo metafísico rígido entre vontade e representação, atribuindo à primeira o estatuto de coisa em si, destituída de todas as formas e predicados da segunda, e criando um amálgama conceitual no qual intelecto, consciência, cognição e representação se fundem no lado oposto ao da vontade. Este amálgama se refere à instância epistêmica que podemos chamar de "eu cognoscente", e sobre o qual Schopenhauer nos diz que ele "está para a vontade, que é a base do fenômeno do mesmo, assim como a imagem no foco do espelho côncavo está para este último, e tem, como aquela, apenas uma realidade condicionada", uma realidade que é na verdade "meramente aparente". Longe de ser a entidade absolutamente primeira, como queria Fichte por exemplo, "ele é, no fundo, terciário, na medida em que pressupõe o organismo, e este, por sua vez, a vontade" ${ }^{\text {, }}$, realidade e fundamento último de todos os fenômenos.

Desse modo, com a atribuição de um caráter inconsciente e não-cognitivo à vontade, ela é então contraposta às atividades cognitivas conscientes do intelecto e designada como um impulso cego que rege toda a dinâmica do nosso ser. A própria unidade do eu (vista como meramente aparente) é tornada ontologicamente dependente

\footnotetext{
${ }^{8}$ SCHOPENHAUER, A. WWV II/MVR II, 314s.
} 
da unidade inconsciente da vontade, a qual produz aquela coordenação egóica das atividades intelectuais conscientes como ferramenta para a realização de seus próprios fins. As implicações dessa tese nuclear do primado da vontade sobre o intelecto no âmbito de uma análise psicológica conduzem a uma visão do mecanismo psíquico semelhante àquela desenvolvida por Freud em sua metapsicologia. Porém, no caso de Schopenhauer, a tese do primado da vontade é fundada metafisicamente, o que compromete o filósofo com uma ontologia do inconsciente muito mais robusta do que a que encontramos em Freud. O domínio inconsciente da vontade é concebido como a verdadeira essência tanto da vida psíquica como da própria materialidade do corpo. Segundo essa concepção, a morfologia do organismo é determinada segundo os fins inconscientes da vontade aos quais cada uma de suas partes corresponde.

Uma vez que o intelecto e a consciência, isto é, o conjunto de nossas faculdades cognitivas, são produzidos pela vontade para a satisfação de suas necessidades e a realização de seus fins, e uma vez que a vontade é ela mesma inteiramente desprovida de consciência, o que se extrai daí em termos de psicologia é um quadro explicativo no qual ações e pensamentos individuais são reconduzidos a uma conformidade a fins que transcende o horizonte intencional do próprio indivíduo, mas que deriva ainda de sua constituição interna mais profunda ${ }^{9}$. No âmbito dessas análises psicológicas, que envolvem uma explicação teleológica das formas de objetivação da vontade, encontramos, contudo, uma descrição dos mecanismos inconscientes em ação na nossa vida mental e corporal que recorre ainda assim a um vocabulário profundamente intencionalista. Trata-se nesse caso de uma intencionalidade agindo no nível inconsciente-pulsional. Com efeito, a vontade "proíbe" ao intelecto certas representações ou "não permite" que certos pensamentos venham à tona, pois "sabe" que eles provocariam certos sentimentos e emoções desagradáveis ou prejudiciais; ela então "redireciona" o intelecto a outras representações; ela tem "inclinações" a certas representações e "aversão" por outras, ou inclinação a uma representação "numa determinada perspectiva", mas não em outra; uma representação pode ou não lhe ser "interessante"; ela "decide" em razão de um "conhecimento" acerca da conformidade a fins ou da ausência desta num determinado objeto e "obriga" então o intelecto a

\footnotetext{
${ }^{9}$ Cf. GARDNER, S. Schopenhauer, Will, and the Unconscious, p. 379.
} 


\section{WILLIAM MATTIOLI}

obedecer suas ordens ${ }^{10}$. Se tomarmos essa passagem seriamente, deveremos atribuir à vontade um tipo de intencionalidade. Apesar da insistência de Schopenhauer quanto ao caráter não-cognitivo da vontade, não podemos deixar de notar que quando se trata de descrever os mecanismos psíquicos mobilizados por ela na manifestação de seus atos o vocabulário usado é inteiramente intencionalista. Até mesmo um determinado tipo de "conhecimento" lhe é atribuído. Aqui, a tese central do primado da vontade na vida psíquica é defendida por meio de uma análise acurada apoiada em observações perspicazes da dinâmica envolvida nos processos mentais, na qual destaca-se uma profunda interação entre processos volitivos e cognitivos.

Porém, como já mencionado, o termo "vontade" designa em Schopenhauer tanto a dimensão imanente de nossa vida pulsional quanto a essência transcendente do nosso ser (e do ser em geral). Enquanto tal, ela deve ser vista como o lado oposto da representação, inteiramente estranho a esta e que está na base de todo fenômeno, ao passo que a representação se refere meramente ao lado do mundo existente em nossa consciência. Essa é a razão que conduz Schopenhauer a uma concepção estritamente dualista na qual a vontade deve ser pensada como absolutamente livre das formas da representação e do princípio de razão. Com isso, uma teoria realista da vontade é associada a uma tese idealista acerca do modo como nos representamos o mundo, e a própria realidade do sujeito autoconsciente é rebaixada à categoria de mera ilusão.

Essa associação entre realismo e idealismo, somada à tese do caráter cego da vontade e do caráter ilusório do "eu", faz com que Schopenhauer ocupe uma espécie de "não-lugar" no contexto da filosofia transcendental. Por mais que ele se arrogue o título de herdeiro da filosofia kantiana, assumindo a tese de que o mundo que conhecemos é constituído pelas formas de nossa faculdade cognitiva e que para além dele há um registro noumenal, o modo como ele opera a transição da epistemologia para a metafísica fere pelo menos dois pressupostos básicos de uma teoria transcendental que se pretenda herdeira legítima do transcendentalismo kantiano (esteja ela vinculada a um idealismo subjetivo ou a um idealismo objetivo): 1) em primeiro lugar, a teoria genético-transcendental de Schopenhauer, que descreve o modo como o entendimento individualisa as afecções sensíveis convertendo-as em objetos empíricos, é destituída de sua prerrogativa teórica ao descobrirmos que o mecanismo cognitivo não age de modo

\footnotetext{
${ }^{10}$ SCHOPENHAUER, A. WWV II/MRV II, p. 233 (grifos nossos).
} 
autônomo, uma vez que sua espontaneidade é derivada da vontade ${ }^{11}$, estando submetida aos seus ditames e às suas formas de manifestação. Desse modo, a autoconsciência intelectiva perde a legitimidade e prioridade epistêmica e metodológica da qual gozava no registro da filosofia transcendental e que conferia a esta sua especificidade; 2) em segundo lugar, a compreensão schopenhauriana da relação entre fenômeno e coisa em si é totalmente estranha à teoria kantiana e vai de encontro aos limites críticos estabelecidos pela filosofia transcendental segundo os quais só estamos autorizados a teorizar acerca daquele âmbito de objetos cuja natureza e relação reproduz e está em consonância com nossas estruturas subjetivas.

No que concerne a este segundo ponto, o modo como Schopenhauer entende a relação entre fenômeno (representação) e coisa em si (vontade) é totalmente estranho ao modo como Kant a compreende uma vez que a vontade schopenhaueriana é imanente ao fenômeno e se revela ao filósofo tão logo este se empenhe em decifrar a escrita do mundo. Ao contrário de Kant, para quem a noção de coisa em si funciona como uma espécie de corolário de sua teoria transcendental da experiência, estando portanto subordinada a esta enquanto conceito-limite, Schopenhauer concebe sua coisa em si como o fundamento explicativo de todo fenômeno, isto é, como o não-fenomênico que se manifesta primordialmente no fenômeno segundo diferentes graus de objetivação e complexidade $^{12}$. Com isso, sua teoria transcendental da individuação termina por assumir uma posição secundária frente aos desdobramentos de sua concepção da coisa em si, uma vez que nesse contexto o mundo como representação deve ser entendido como tendo uma origem metafísica ${ }^{13}$.

Por fim, esse aspecto se torna ainda mais evidente se temos em mente o outro ponto mencionado acima, a saber, que a forma como Schopenhauer articula os predicados da vontade em oposição aos predicados da representação implica um ultrapassamento dos limites estabelecidos pela filosofia transcendental na medida em

\footnotetext{
${ }^{11} \mathrm{Cf}$. SCHOPENHAUER, A. WWV II/MVR II, p. 312.

${ }^{12}$ Cf. GARDNER, S. Schopenhauer, Will, and the Unconscious, p. 395.

13 Rudolf Malter observa a esse respeito que, com a entrada em cena da metafísica da vontade, o "transcendentalismo da representação" (que corresponde ao lugar ocupado pelo idealismo subjetivo de Kant no sistema schopenhauriano) "perde seu significado autônomo". Tão logo ela está em jogo, "tornase clara por um lado a função preparatória da filosofia transcendental kantiana, por outro sua superação" (MALTER, R. Arthur Schopenhauer. Transzendentalphilosophie und Metaphysik des Willens, p. 244s.) A metafísica da vontade "define o transcendentalismo como a disciplina secundária" (Ibid., p. 262). O complexo desenvolvimento da argumentação de Malter acerca do lugar do transcendentalismo na filosofia de Schopenhauer será discutido nas últimas seções deste trabalho.
} 
que reivindica legitimidade para uma explanação teórica da natureza que concerne a um domínio de objetos cujos traços estruturais não podem ser reconduzidos a um "transcendental". Nesse sentido, podemos dizer, por um lado, que o idealismo de Schopenhauer não é transcendental no sentido kantiano; por outro, ele tampouco pode ser definido como um idealismo objetivo, uma vez que a vontade deve ser entendida como totalmente estranha às formas segundo as quais o mundo como representação é construído. Enquanto o transcendentalismo (tanto no idealismo subjetivo quanto no objetivo) exige que todos os traços estruturais da natureza sejam remetidos a funções de um certo tipo de subjetividade criadora de formas, a metafísica da vontade de Schopenhauer trata a natureza como manifestação de uma realidade subjacente que é absolutamente alheia a qualquer tipo de subjetividade transcendental ${ }^{14}$. Essa tentativa de vincular realismo não-transcendental e idealismo subjetivo conduziu Schopenhauer ao que talvez seja o maior paradoxo do seu sistema, ao qual ele deu o nome de antinomia de nossa faculdade de conhecimento, e que diz respeito à incongruência entre as considerações subjetiva e objetiva do intelecto, segundo denominação do próprio autor. Essa antinomia, por outro lado, é o que faz do edifício conceitual schopenhauriano o "palco de um debate vivo e em última instância inconcluso", como diz Alfred Schmidt ${ }^{15}$. A "peculiar circularidade e interrelação" que caracteriza a convivência belígera de tendências idealistas e materialistas em sua filosofia resulta numa estrutura de pensamento caleidoscópica que traz à luz de modo perspectivista as tensões internas assim como os limites externos de cada uma daquelas tendências ${ }^{16}$.

\footnotetext{
${ }^{14}$ Cf. GARDNER, S. Schopenhauer, Will, and the Unconscious, p. 397s.

${ }^{15}$ SCHMIDT, A. Schopenhauer und der Materialismus, p. IX.

${ }^{16}$ Essa relação cheia de tensões entre materialismo e idealismo vêm à tona sobretudo com a assim chamada consideração objetiva do intelecto, presente no segundo volume do Mundo e que comparece em geral nos escritos publicados a partir de Sobre a vontade na natureza. Na literatura, isso conduziu à tese corrente de uma gradual naturalização do pensamento de Schopenhauer e de uma virada materialista em sua trajetória - poderíamos falar ainda, como Schmidt, em uma "autocorreção epistemológica" ou uma "reformulação naturalista do transcendentalismo kantiano" - após a publicação do primeiro volume do Mundo, e isso sob influência de autores como Flourenz, Cabanis e Bichat (cf. LANGBEHN, Metaphysik der Erfahrung. Zur Grundlegung einer Philosophie der Rechtfertigung beim frühen Nietzsche, p. 60s.; SCHMIDT, Schopenhauer und der Materialismus, p. XXV; SCHMIDT, A. Physiologie und Transzendentalphilosophie bei Schopenhauer, p. 43s.). Essa abordagem genética, muito bem representada por Eduardo Brandão em seu livro A concepção de matéria na obra de Schopenhauer, aposta num progressivo distanciamente de Schopenhauer da herança kantiana que ainda prevalecia no primeiro volume de sua obra principal (cf. BRANDÃO, E. A concepção de matéria na obra de Schopenhauer, p. $17 \mathrm{~s}$; ; cf. ainda p. 229 ss. para uma rigorosa análise do desenvolvimento do "ponto de vista objetivo" com base num detalhamento e numa revisão estrutural da noção de causalidade concomitantemente a uma sofisticação do argumento da analogia por Schopenhauer a partir de Sobre a vontade na natureza.) Como ficará mais claro nas seções seguintes, nossa leitura não tem como foco essa abordagem genética, mas
} 


\section{A consideração objetiva do intelecto e o caráter instrumental do conhecimento}

O capítulo 22 do segundo volume do Mundo é dedicado a uma análise do intelecto a partir do assim chamado ponto de vista objetivo. Mas o que Schopenhauer quer dizer com o termo "objetivo" nesse contexto? No Livro I do primeiro volume da obra, o intelecto e a consciência haviam sido tratados segundo um ponto de vista subjetivo, qualificação que se refere ao tipo de análise que toma como ponto de partida a consciência (experiência interna) como um dado e, desdobrando-se por assim dizer "a partir de dentro", apresenta o mecanismo interno mediante o qual o mundo se nos apresenta e é pensado como representação por intermédio dos sentidos, do entendimento e da razão. Trata-se aqui da perspectiva fundamentalmente idealista herdada (não sem alguns ajustes) de Kant. Contudo, Schopenhauer acusa Kant de unilateralidade por haver se ocupado somente com essa perspectiva subjetiva (idealista), deixando de lado um aspecto que ele considera essencial para uma compreensão e uma explanação completa dos nossos mecanismos cognitivos. Ao considerar nossa faculdade de conhecimento somente segundo o ponto de vista subjetivo, revelando os elementos $a$ priori através dos quais o mundo fenomênico é construído, Kant não teria notado a importância de uma investigação fisiológica capaz de nos fornecer informações cruciais para entendermos a natureza e a função de nossas faculdades cognitivas em termos de sua relação genética com o mundo externo. Nesse sentido, Schopenhauer pretende complementar a perspectiva subjetiva através de uma consideração objetiva do intelecto, que toma como ponto de partida não a consciência, mas sim o mundo tal como nos é dado na experiência externa. Partindo então das relações e interações físicas, químicas e biológicas do mundo exterior, essa análise tem por fim colocar à mostra as condições empíricas mediante as quais se tornou possível e necessário o surgimento de um mecanismo cognitivo. Desse modo, essa consideração leva a cabo uma investigação genético-etiológica do conhecimento capaz de nos informar de modo mais completo acerca de sua natureza, sua origem, sua função e seus limites ${ }^{17}$.

sim a questão sistemática acerca da incompatibilidade entre as diversas exigências teóricas da metafísica da vontade, por um lado, e por outro os pressupostos básicos do idealismo subjetivo de cunho kantiano professado por Schopenhauer.

17 Cf. SCHOPENHAUER, A. WWV II/MVR II, p. 308ss. Para Christopher Janaway, a crítica de Schopenhauer à concepção unilateral de Kant acerca do sujeito e sua tentativa de complementá-la através 


\section{WILLIAM MATTIOLI}

Se considerarmos inicialmente, dentro desse contexto, a pergunta pela origem do conhecimento, nos depararemos com uma resposta de Schopenhauer que reconduz nosso aparato cognitivo como um todo a uma função do cérebro. Todo o mundo objetivo que apreendemos intuitivamente e todo o aparato conceitual que construímos para compreendê-lo podem ser reduzidos, nesse nível teórico, a certos movimentos e alterações na massa encefálica. O cérebro, por sua vez, é uma formação orgânica resultante de um aglomerado de matéria extremamente refinado capaz de converter as mínimas excitações numa ampla representação imagética de um mundo objetivo. Enquanto formação orgânica, o cérebro não possui uma natureza distinta das formações orgânicas inferiores, diferenciando-se delas somente por sua complexidade. Ele é o último produto da natureza e pressupõe todos os outros na série causal da escala evolutiva. Mas o que teria levado a natureza a produzir algo como um aglomerado orgânico dotado de capacidades cognitivas? Aqui, a etiologia é complementada por uma Naturphilosophie; poderíamos dizer até mesmo que, nesse registro conceitual, a primeira é destituída de sua função explicativa pela segunda. Com efeito, a resposta de Schopenhauer remonta à sua concepção metafísica da natureza para fornecer uma explicação do "por quê", ou melhor, do "para quê" do conhecimento: trata-se da vontade, esse impulso insaciável que está essencialmente por trás de todo fenômeno manifestando-se como natureza: como forças naturais primordiais (ursprüngliche Naturkräfte) e como força vital (Lebenskraft); é a busca pela satisfação de necessidades cada vez mais delicadas e complexas que leva a natureza à produção de organismos com morfologias cada vez mais adaptadas ao caráter sutil dessas necessidades. Como observa Rudolf Malter, a concepção de uma interação fundamental da vontade com o fenômeno torna clara a preponderância concreta da primeira nos efeitos do mundo material: "sob a forma das forças primordiais da natureza, é ela (e não o princípio de razão) que determina de modo primário os processos naturais", enquanto as causas pertencentes à dimensão do fenômeno (isto é, das causas mecânicas até as excitações e os motivos) têm apenas uma função ocasional - são "causas eventuais"18. Em última

de uma abordagem empírico-materialista é a maior realização de sua filosofia. Mesmo que essa tentativa o conduza a um problema em grande parte insolúvel, ter reconhecido o caráter incompleto e unilateral do idealismo kantiano e ter assim buscado um ponto de vista além, na tentativa de conciliar as abordagens subjetiva e objetiva, deve ser visto como um enorme progresso em relação a Kant. (Cf. JANAWAY, C. Self and World in Schopenhauer's Philosophy, p. 186).

18 MALTER, R. Arthur Schopenhauer. Transzendentalphilosophie und Metaphysik des Willens, p. 260. Sobre a ideia de uma atividade original da matéria (Materie) relacionada a uma força intrínseca de 
instância, portanto, o conhecimento e o intelecto, como funções de um órgão produzido pela vontade no mundo fenomênico, são apenas instrumentos desta última.

Ora, com a pergunta pela origem já tocamos também diretamente nas questões acerca da natureza e da função do conhecimento, e indiretamente na questão acerca de seus limites. Como mecanismos da vontade com vistas à satisfação das necessidades do organismo, o intelecto e o conhecimento têm uma natureza instrumental e uma função pragmática de orientação no mundo. É através da apreensão cognitiva do mundo enquanto mundo de entes individuados no espaço que o organismo animal é capaz de perseguir seus fins, de movimentar suas partes de modo a alcançar o objeto de seu anseio e satisfazer seus desejos ou instintos. Na medida em que fornece uma percepção do ambiente circundante (por mais precária que seja esta percepção nos organismos inferiores), o conhecimento funciona assim como um meio para a representação dos motivos da ação de um determinado animal, aquilo para o qual ele deverá direcionar seus esforços. Schopenhauer define o motivo como:

um estímulo externo, cujo efeito dá origem primeiramente a uma imagem no cérebro, por meio da qual a vontade realiza o verdadeiro efeito, a ação corporal externa. Na espécie humana, porém, é possível que um conceito, abstraído de imagens anteriores deste tipo através da subtração de suas diferenças, ou seja, que não é mais intuitivo, mas é fixado e designado meramente por palavras, assuma o lugar daquela imagem ${ }^{19}$.

Em última instância, todos os esforços de qualquer organismo estão dirigidos inconscientemente à preservação e à reprodução. Na busca incessante pela preservação e reprodução da vida, à qual a vontade impele categoricamente todo ser vivente, cada órgão possui um fim e uma função determinados. A função do cérebro se realiza pelo mecanismo cognitivo do intelecto.

Uma vez estabelecidas a natureza instrumental e a função pragmática do intelecto, segue-se daí, segundo Schopenhauer, que o conhecimento não tem e não pode ter como objeto a verdadeira essência das coisas. Ele está circunscrito ao âmbito relacional do mero fenômeno. A intuição nos fornece um conhecimento intuitivo do mundo como representação; a razão e os conceitos, derivados da intuição e fixados

mudança que não necessita de uma causa mecânica externa pois remete diretamente à vontade, cf. ainda BRANDÃO, E. A concepção de matéria na obra de Schopenhauer, pp. 191-195.

${ }^{19}$ SCHOPENHAUER, A. N/N, p. 313. 


\section{WILLIAM MATTIOLI}

como representações de segundo grau, nos fornecem um conhecimento abstrato desse mesmo mundo. Estamos aqui no âmbito das relações intrafenomenais, onde rege o princípio de razão. Para Schopenhauer, a subordinação dos mecanismos cognitivos às necessidades inconscientes do organismo torna ilegítima qualquer reivindicação a um acesso epistêmico à verdadeira essência do mundo. E isso porque o intelecto, originalmente designado para apresentar à vontade individual a representação de seus motivos, "consequentemente apreende meras relações das coisas e não penetra em seu interior, em sua essência própria"20.

Numa tentativa um tanto quanto forçada de assegurar seu lugar entre os legítimos herdeiros da filosofia kantiana, Schopenhauer identifica aqui o pensamento fundamental do qual teria nascido a Crítica da razão pura de Kant. Para ele, a tese segundo a qual não dispomos de nenhum tipo de material cognitivo (seja por meio da intuição, seja por meio dos conceitos abstratos) que nos forneça um conhecimento do mundo tal como ele é em si mesmo - razão pela qual ao nos lançarmos em um tal empreendimento epistêmico sempre nos enveredaremos em embaraços teóricos inextricáveis -, provém da constatação de que “o intelecto, e portanto o próprio conhecimento, é algo secundário, um mero produto, engendrado a partir do desdobramento da essência do mundo" 21 . Nesse sentido, ele seria dependente da história evolutiva do próprio mundo e dos organismos que o habitam, surgindo como uma espécie de luz das profundezas obscuras da vontade cega, esta que é em si privada de qualquer tipo de mecanismo cognitivo ou intencional. Esta vontade, portanto, na medida em que está na base do conhecimento como sua condição, não pode ser por ele apreendida, não pode se tornar seu objeto: “Aquilo que antecede o conhecimento como sua condição, através do que ele se tornou pela primeira vez possível, isto é, sua própria base, não pode ser apreendido por ele imediatamente; assim como o olho não pode ver a si mesmo." 22

Nesta passagem, Schopenhauer atribui à vontade um estatuto transcendental ao considerá-la como condição de possibilidade do conhecimento. Aqui, os resultados da análise transcendental do conhecimento levada à cabo por Kant são constatados sobre uma base naturalista e aliados aos resultados das ciências naturais, em particular da

\footnotetext{
${ }^{20}$ SCHOPENHAUER, A. WWV II/MVR II, p. 325.

${ }^{21}$ Ibid., p. 326.

${ }^{22}$ Ibid.
} 
fisiologia. Mais ou menos do mesmo modo que metafísica e ciência natural são associadas neste ponto da investigação filosófica, a vontade adquire ao mesmo tempo e de um modo um tanto quanto paradoxal o estatuto de transcendente e transcendental com relação ao conhecimento. Por sua vez, o estabelecimento dos limites do conhecimento se dá por meio de uma constatação do seu caráter instrumental: por ser um produto do desdobramento e da exteriorização da própria essência do mundo no seio da natureza, ele está essencialmente condicionado por ela e é consequentemente incapaz de se colocar diante dela para apreendê-la objetivamente.

Constata-se assim que a crítica da razão realizada por Schopenhauer é metafisicamente motivada. Mobilizando uma ontologia inteiramente avessa aos princípios do transcendentalismo kantiano, ele acredita estar ainda mais justificado a se engajar no empreendimento de crítica do conhecimento do que o próprio Kant. Essa convicção tem basicamente duas razões: a) em primeiro lugar, sua análise do conhecimento seria mais completa do que a análise unilateral de Kant por considerar nosso aparato cognitivo não somente do ponto de vista subjetivo próprio ao idealismo, mas também a partir do ponto de vista objetivo, fisiológico; b) por sua vez, a legitimidade desta consideração objetiva é concedida pela tese metafísica de que por trás de todo fenômeno está a vontade, que se manifesta como natureza produzindo formações orgânicas em gradativa evolução. Com sua suposta ontologia crítica, Schopenhauer acredita ter ido além de uma certa obtusidade de Kant, que teria sido incapaz de reconhecer a existência de uma fonte imanente legítima de conhecimento metafísico. O autor da Crítica da razão pura teria ignorado que, apesar do conhecimento objetivo estar circunscrito somente ao mundo dos fenômenos (o mundo como representação), nossa própria essência pertence ao mundo da coisa em si, na medida em que está nele enraizada. Esse enraizamento do sujeito no mundo da coisa em si tornaria possível que ele, através de um redirecionamento do olhar à dimensão volitiva do corpo próprio, obtivesse uma compreensão não objetivante da relação existente entre o fenômeno e sua essência mais íntima.

É a partir dessa reviravolta naturalista e metafísica situada nos meandros de um idealismo em crise que Schopenhauer afirmará a superioridade de sua própria análise crítica frente àquela de Kant. $\mathrm{O}$ resultado dessa reviravolta é, por um lado, um enorme progresso em direção a uma epistemologia cientificamente esclarecida que antecipa em 


\section{WILLIAM MATTIOLI}

vários aspectos o projeto de naturalização do kantismo que dominou boa parte do cenário intelectual alemão da segunda metade do século XIX. Por outro lado, porém, ela resulta num abandono inconfesso por parte de Schopenhauer de um aspecto central do método transcendental que caracterizava o idealismo kantiano.

Ao se posicionar com relação à crítica da razão de Kant, o filósofo da vontade nos diz que este último procedeu de modo a posteriori na análise dos limites do conhecimento $^{23}$. O que leva Schopenhauer a fazer tal afirmação? Segundo ele, o caminho percorrido por Kant, ao constatar a inadequação do conhecimento racional para uma explicação da essência do mundo, toma como ponto de partida o próprio conhecimento, considerando-o como um fato, para então prosseguir investigando até onde poderíamos avançar com seu auxílio. O emprego que Schopenhauer faz aqui do termo "a posteriori" parece não coincidir exatamente com uso que o próprio Kant faz do conceito, o que leva a crer que ele esteja cometendo uma certa injustiça ao qualificar o argumento kantiano acerca dos limites do conhecimento como a posteriori. Com efeito, a distinção kantiana entre fenômeno e coisa em si, na qual se encontra necessariamente implicada a ilegitimidade de um uso transcendente dos conceitos do entendimento, não recebe por acaso o nome de distinção transcendental ${ }^{24}$. Trata-se claramente de uma distinção feita a priori, uma vez que ela não depende do apelo à experiência para que sua validade epistêmica esteja assegurada (do contrário, a questão se podemos ou não conhecer as coisas tal como elas são em si mesmas não poderia ser respondida com certeza apodítica e estaria sujeita à contingência).

De todo modo, o aspecto do procedimento crítico de Kant que Schopenhauer pretende ressaltar ao caracteriza-lo como a posteriori parece remeter à indisposição kantiana em questionar seu ponto de partida: a factualidade do conhecimento científico em sua necessidade e universalidade. Os limites do conhecimento são estabelecidos por Kant a posteriori na medida em que o fato do conhecimento é tomado como algo imediatamente dado e certo a priori, e o filósofo, ao invés de proceder geneticamente no sentido de um questionamento radicular de sua validade mediante uma investigação de sua natureza e origem, procede analiticamente e dedutivamente com vistas a estabelecer suas condições de legitimação. É somente por ocasião do estabelecimento dos critérios e das condições de validade objetiva de nossos juízos que Kant instaura ao

${ }^{23}$ Cf. Ibid., p. 328.

${ }^{24}$ Cf. KANT, I. Crítica da razão pura, A45-B62. 
mesmo tempo os limites do conhecimento: só podemos ter conhecimento daquilo que nos é dado na intuição uma vez que é só nesse registro que os conceitos adquirem um conteúdo objetivo. Schopenhauer, por sua vez, declara que seu movimento argumentativo para provar a insuficiência do conhecimento com vistas à coisa em si é $a$ priori, diferentemente de Kant. E isso porque ele teria chegado a essa conclusão a partir de um procedimento genético, a partir de uma análise do conhecimento segundo sua natureza e origem, trazendo à tona seu caráter secundário enquanto instrumento da vontade. Dentro desse contexto, o conhecimento não poderia ser visto como ponto de partida da investigação (como ocorre em Kant), uma vez que ele é ponto de chegada da história material de exteriorização da vontade. Essa é a razão pela qual ele teria de ser necessariamente inconclusivo no que diz respeito à pergunta pela essência do mundo.

Ora, reconduzir o mecanismo representacional à sua origem metafísica (como rebento da vontade) forneceu a Schopenhauer um outro caminho para o estabelecimento dos limites do conhecimento. Entretanto, esse caminho destoa do método transcendental kantiano num ponto fundamental: o tipo de explanação filosófica empregada na filosofia transcendental não é e não pode ser de modo algum baseado num apelo a um conhecimento acerca da constituição essencial, seja do sujeito, seja das coisas do mundo $^{25}$. Já havíamos visto que a forma como Schopenhauer articula os predicados da vontade em contraposição ao mundo da representação fere os princípios de qualquer tipo de transcendentalismo na medida em que pretende descrever um domínio de objetos cujas estruturas não podem ser remetidas a funções de um tipo de subjetividade transcendental. De acordo com o que acabamos de ver, sua crítica do conhecimento, por sua vez, por mais paradoxal que isso possa soar, se baseia na reivindicação de um acesso epistêmico a esse mesmo domínio transcendente no qual estão ausentes todas as formas de articulação dos predicados da representação. Há um duplo paradoxo nesse empreendimento crítico-metafísico que pretende determinar os limites do conhecimento e provar sua insuficiência face à pergunta pela essência. Com efeito, esse empreendimento é realizado a partir de um modelo científico (fisiológico), cuja função explicativa depende justamente de um saber metafísico acerca da essência do mundo. Além disso, ele se envereda em embaraços insuperáveis no tocante aos pressupostos naturalistas da tese de um desdobramento material gradativo da vontade. Esse duplo

\footnotetext{
${ }^{25}$ Cf. GARDNER, S. Schopenhauer, Will, and the Unconscious, p. 394.
} 
paradoxo se revela como uma consequência daquele problema fundamental que emerge da tentativa schopenhauriana de conciliar realismo (não-transcendental) e idealismo subjetivo. No que se segue analisaremos alguns dos aspectos desse problema concernente à tensão entre naturalismo e transcendentalismo no pensamento de Schopenhauer.

\section{Naturalismo e transcendentalismo: a antinomia da faculdade de conhecimento}

Ao abandonar as premissas do idealismo transcendental em sua metafísica, complementando-a enfim com uma teoria da evolução orientada cientificamente, Schopenhauer é obrigado a se confrontar com uma contradição que é elaborada por ele de dois modos distintos. Ainda no livro I do primeiro volume de sua obra principal, ao falar sobre a lei de causalidade, o autor nos apresenta a primeira formulação do paradoxo. Com efeito, a lei de causalidade e a investigação científica da natureza que a toma como fio condutor implicam que:

no tempo, qualquer estado da matéria mais complexamente organizado deve ter sido precedido de um mais simples, vale dizer, que os animais existiram antes dos homens, os peixes antes dos animais, as plantas antes destes e o inorgânico antes de qualquer orgânico; por consequência, a massa originária passou por uma longa série de mudanças antes que o primeiro olho pudesse se abrir. E no entanto a existência daquele mundo inteiro permanece sempre dependente desse primeiro olho que se abriu, tenha ele pertencido até mesmo a um inseto [...]. Sim, toda aquela longa série temporal, cheia de inumeráveis mudanças, mediante as quais a matéria ascendeu de forma a forma até a existência do primeiro animal cognoscente, toda essa longa série, ela mesma, só pode ser pensada unicamente na identidade de uma consciência. [...] Assim, necessariamente, vemos de um lado a existência do mundo todo dependente do primeiro ser que conhece, por mais imperfeito que seja; de outro, vemos esse primeiro animal cognoscente inteiramente dependente de uma longa cadeia de causas e efeitos que o precede e na qual ele aparece como um membro diminuto $^{26}$.

A esse curto circuito essencial no interior de seu sistema Schopenhauer dá o nome de "antinomia em nossa faculdade de conhecimento". Trata-se de um dilema epistemológico insuperável, o que pode ser constatado, dentre outras coisas, pelo fracasso da tentativa schopenhaueriana de dissolução da antinomia. Schopenhauer

\footnotetext{
${ }^{26}$ SCHOPENHAUER, A. WWV I/MVR I, § 7, p. 75s.
} 
acredita ser capaz de solucionar esse paradoxo reiterando a tese herdada de Kant segundo a qual "tempo, espaço e causalidade não pertencem à coisa em si, mas exclusivamente ao seu fenômeno"27. Essa tentativa de solução um tanto quanto leviana se encontra na sequência da passagem acima citada. Ao reforçar a afirmação de que a representação corresponde apenas a um lado do mundo, seu "lado exterior", e de que o mundo possui ainda um lado interior, completamente diferente, que será tratado no livro seguinte, ele deixa o leitor na expectativa de que o problema será definitivamente solucionado posteriormente. Contudo, Schopenhauer apenas procrastina a resolução da antinomia, cuja solução permanece insatisfatória, pois a metafísica da vontade, com sua explicação teleológica do desenvolvimento material e gradual das formações orgânicas, encerra em si, desde o início e até seus paralipomena distintamente científicos, esse problema fundamental.

Uma das razões que tornam o dilema epistemológico aqui presente insuperável é o fato de que cada uma das estratégias argumentativas (a argumentação transcendentalidealista por um lado, e a empírico-materialista por outro) pressupõe a outra. Se por um lado o sujeito é condição de possibilidade da história material das manifestações da vontade, por outro ele não é senão um produto, um ponto de chegada dessa evolução. No capítulo VI do livro II de Parerga e Paralipomena, "Sobre a filosofia e a ciência da natureza", encontramos a seguinte formulação da antinomia:

\begin{abstract}
Se, por um lado, devemos admitir que todos aqueles processos físicos, cosmogônicos, químicos e geológicos existiram antes do surgimento da consciência e portanto fora de uma consciência, uma vez que, como suas condições, eles necessariamente devem ter precedido seu surgimento; por outro lado não se pode negar que esses mesmos processos nada são fora de uma consciência e não podem sequer ser pensados, uma vez que é somente em e por meio de suas formas que eles podem se manifestar. No melhor dos casos poderíamos dizer que a consciência condiciona os processos físicos em questão em virtude de suas formas; mas ela é, por sua vez, condiciona por eles em virtude da matéria destes ${ }^{28}$.
\end{abstract}

Vemos aqui um duplo condicionamento entre sujeito (consciência) e matéria que torna o sistema de Schopenhauer bastante indigesto ${ }^{29}$. Ao lado de alguns outros críticos,

\footnotetext{
${ }^{27}$ Ibid., p. 76.

${ }^{28}$ SCHOPENHAUER, A. P II/P II, p. 150.

${ }^{29}$ A estranheza dessa ideia se reflete ainda em outras formualções de Schopenhauer, como por exemplo quando ele analisa o conhecimento em termos de uma "modificação" da matéria e ao mesmo tempo
} 
um dos discípulos mais honestos de Schopenhauer, o jovem Nietzsche, percebeu esse problema bem cedo. Sob influência de um texto de Rudolf Haym sobre Schopenhauer ${ }^{30}$, ele identificou a questão acerca da origem do intelecto e dos limites da individuação como o paradoxo central da filosofia de seu mentor intelectual. Em algumas anotações escritas entre os anos de 1867 e 1868 e que levam o título "Sobre Schopenhauer", Nietzsche se pergunta como uma vontade alheia ao princípio de razão (grundlos), alheia a qualquer atributo cognitivo (erkenntnislos) e atemporal (zeitlos) pode vir a se tornar fenômeno, manifestando-se em entidades individuadas. Posto de outro modo: "de onde [provém] o aparato representacional no qual a vontade aparece?"31 Em sua consideração da natureza orientada segundo as ciências etiológicas, na qual a natureza é vista como objetivação progressiva da vontade, Schopenhauer concebe uma gradação de fenômenos da vontade "com necessidades de existência cada vez maiores: para satisfazê-las, a natureza se serve de uma série gradual correspondente de meios, dentre os quais tem lugar o intelecto, desde a sensação mais incipiente até a sua extrema clareza.” Essa tese naturalista concernente aos graus de objektivação da vontade pressupõe, portanto, que a individuação e suas formas: tempo, espaço e causalidade, já existem antes do surgimento do intelecto, pois sem elas é inconcebível qualquer desenvolvimento do orgânico. Nietzsche retira então as consequências dessa tese no interior do sistema schopenhauriano:

considera a matéria como uma "modificação" do conhecimento (cf. WWV I/MVR I, §7, p. 73; WWV II/MVR II, p. 15). De modo bastante sofisticado, Alfred Schmidt chama atenção para a equivocidade dessas passagens, sobretudo com relação ao uso do termo "modificação". O modo pelo qual a existência de uma mente cognoscitiva remete à existência da matéria é "qualitativamente diferente" do modo pelo qual a existência da matéria remete a uma função cognitiva dessa mesma mente. $O$ fato de que o mecanismo cognitivo é uma função da matéria (do cérebro) constitui o lado "real-genético" da relação entre intelecto e matéria (lado que concerne à história evolutiva dos organismos). Por sua vez, o fato de que todas as afirmações acerca do mundo material só podem ser feitas a partir da pespectiva de um sujeito cognoscente constitui o lado formal-cognitivo da relação em questão. Para Schmidt, o uso que Schopenhauer faz do termo "modificação" nessas passagens é marcado por essa equivocidade (cf. SCHMIDT, A. Schopenhauer und der Materialismus, p. XXVIII e p. XLIV, nota 124). Com efeito, o correlativismo transcendental entre sujeito e objeto não pode ser prontamente traduzido num correlativismo genético-etiológico entre intelecto e matéria. É verdade que Schopenhauer tenta enfim verter mais uma vez a problemática correlação entre intelecto e matéria naquela formalmente menos onerosa entre sujeto e objeto, operação pela qual a primazia da perspectiva transcendental-idealista é assegurada (Ibid., p. XXVIII). Contudo, esse movimento teórico não é capaz de fornecer uma resposta satisfatória à pergunta pela origem do intelecto, que surge com a concepção evolucionista da objetivação da vontade e que é justamente a pergunta mais importante no contexto em questão.

${ }^{30}$ Cf. BARBERA, S. Eine Quelle der frühen Schopenhauer-Kritik Nietzsches. Rudolf Hayms Aufsatz „Arthur Schopenhauer“; LOPES, R. Ceticismo e vida contemplativa em Nietzsche, pp. 126-144; LANGBEHN, C. Metaphysik der Erfahrung. Zur Grundlegung einer Philosophie der Rechtfertigung beim frühen Nietzsche, pp. 121-133.

${ }^{31}$ NIETZSCHE, F. Fragmento 57[55] do outono de 1867 até primavera de 1868, KGW I/4, p. 425. 
numa tal concepção, um mundo fenomênico é colocado antes do mundo fenomênico: se quisermos manter os termos schopenhaurianos acerca da coisa em si. Já antes do aparecimento do intelecto vemos o principium individuationis, a lei de causalidade, em plena efetividade. ${ }^{32}$

Notemos que o adendo de Nietzsche: "se quisermos manter os termos schopenhaurianos acerca da coisa em si" não é de menor importância. Com efeito, os predicados que Schopenhauer atribui à vontade são retirados de uma contraposição à representação, de modo que ela deve ser entendida como aquilo que é absolutamente diverso à representação. Como algo que se encontra fora da individuação, a vontade se caracteriza por uma unidade incondicionada, o que corresponde ao monismo metafísico do autor do Mundo. Ausência de cognição e atemporalidade são outros atributos que lhe dizem respeito. Deixemos de lado aqui o problema relativo ao atributo da unidade, na medida em que este, apesar dos argumentos de Schopenhauer quanto a este ponto, é derivado da "predicação do "um"”, como nos diz Malter ${ }^{33}$, a qual se refere numericamente ao indivíduo e, nesse sentido, corresponde ao princípio de individuação. Concentremo-nos ao invés disso na questão em torno da origem da própria individuação.

A individuação existe somente na medida em que há um intelecto que perceba o mundo como um mundo de entidades individuadas no espaço. Do que foi dito acima segue-se, porém, que o intelecto, tal como concebido por Schopenhauer, já pressupõe um mundo determinado pelo princípio de individuação e pela lei de causalidade. Pois como seria possível a gênese do intelecto numa esfera atemporal e sem a mediação de relações causais? Como diz Nietzsche: "o que se origina a partir de um tal mundo desmundanizado tem de ser propriamente - segundo as declarações de Schopenhauer coisa em si: ora, ou o intelecto jaz então eternamente fundido à coisa em si como um novo predicado, ou não pode haver intelecto, pois um intelecto jamais poderia ter vindo a ser." Contudo, uma vez que há intelecto, Nietzsche conclui que "ele não pode ser um instrumento do mundo fenomênico, como quer Schopenhauer", mas, antes, tem de ser ele mesmo coisa em si, isto é, vontade ${ }^{34}$. Essa compreensão do intelecto como algo imanente à vontade está, porém, em clara oposição ao dualismo fundamental de

\footnotetext{
32 Ibid.

${ }^{33}$ Cf. MALTER, R. Arthur Schopenhauer. Transzendentalphilosophie und Metaphysik des Willens, p. 254.

${ }^{34}$ NIETZSCHE, F. KGW I/4, p. 426s.
} 
Schopenhauer entre vontade e representação. Um tal idealismo objetivo não pode ser por ele aceito, pois essa aceitação solaparia as bases de sua intuição filosóficoexistencial mais essencial, como veremos na sequência.

A pergunta pela origem e pelos limites da individuação com relação ao desenvolvimento de uma faculdade cognitiva pode ser analisada ainda com base numa outra passagem do segundo volume do Mundo que diz respeito igualmente àquela consideração objetiva científica do intelecto:

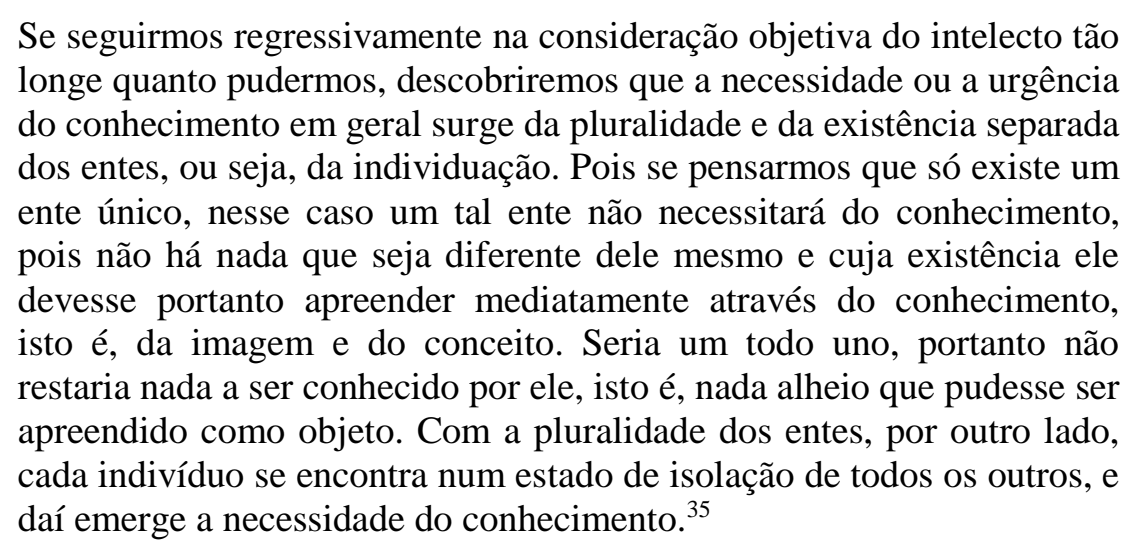

Essa passagem opera uma notável inversão da relação fundacional entre conhecimento e individuação. Segundo a teoria genético-transcendental de Schopenhauer, a individuação (e a pluralidade) tem suas raízes na faculdade subjetiva de conhecimento da qual emergem o tempo, o espaço e a causalidade. Ora, neste trecho, o conhecimento é tornado dependente da existência de uma multiplicidade de indivíduos. De acordo com essa concepção, devemos atribuir pluralidade àquilo que ainda não se manifestou fenomenicamente, isto é, àquilo que ainda não foi percebido pelo intelecto. Se este "aquilo" for a coisa em si, então o monismo schopenhauriano da vontade é solapado. Schopenhauer tenta solucionar esse paradoxo afirmando que o conhecimento e a pluralidade, ou a individuação, dependem um do outro ("stehen und fallen mit einander"), "na medida em que se condicionam mutuamente" 36 . Esse condicionamento mútuo, porém, torna mais uma vez a origem tanto da individuação quanto do conhecimento ininteligível. O dilema epistemológico da associação entre idealismo transcendental e teoria evolucionista aparece aqui mais uma vez em toda sua complexidade, e o paradoxo permanece insuperado. No fundo, a tentativa de

\footnotetext{
${ }^{35}$ SCHOPENHAUER, A. WWV II/MVR II, p. 310.

${ }^{36}$ Ibid., p. 311.
} 
Schopenhauer de solucionar a antinomia de nossa faculdade cognitiva está fadada ao fracasso na medida em que uma solução definitiva obrigaria o autor do Mundo a se decidir entre duas alternativas para ele inaceitáveis: ou abrir mão do idealismo subjetivo de sua epistemologia e do monismo de sua metafísica ${ }^{37}$, ou do evolucionismo científicoetiológico de sua filosofia da natureza.

\section{Considerações sobre a interpretação de Rudolf Malter da metafísica da vontade}

Numa tentativa exemplar de dar uma resposta a essa problemática na filosofia de Schopenhauer e sanar assim a indigestão causada por ela no leitor, Rudolf Malter argumenta que a primazia do ponto de vista transcendental-idealista não é de modo algum ameaçada pela consideração objetiva do intelecto que entra em cena juntamente com a metafísica da vontade. Para ele, a abordagem metafísica e científica daquilo que podemos chamar de "lado subjetivo da representação" declara apenas que o intelecto é também fenômeno e existe materialmente na medida em que é objetivação da vontade, isto é, vontade tornada visível. Schopenhauer nunca teria deixado dúvidas quanto ao fato de que essa perspectiva objetiva de análise do intelecto, por mais valorosa que ela seja enquanto complemento ao transcendentalismo, só é possível na medida em que a perspectiva idealista (subjetiva) já está pressuposta. De acordo com seu argumento, é somente a partir deste ponto de vista que a razão chega ao conhecimento da vontade e, consequentemente, ao conhecimento de que o aparato cognitivo é também fenômeno, isto é, objetivação da vontade, na medida em que também possui uma existência material (o cérebro) ${ }^{38}$. Não haveria portanto em Schopenhauer nenhuma tendência fundamental ao materialismo capaz de suprimir seu compromisso global com o idealismo transcendental. Desse modo, o paralipomenon de sua metafísica, proveniente do labor das ciências naturais, não teria direito ao nobre título concedido à concepção legitimadora do sistema, herdeira da filosofia transcendental, e lhe permaneceria subordinado.

Mas essa dialética morganática entre idealismo e naturalismo (materialismo) não parece apresentar uma solução satisfatória. Como o próprio Malter observa,

\footnotetext{
${ }^{37}$ Cf. LOPES, R. Ceticismo e vida contemplativa em Nietzsche, p. 138s.

${ }^{38}$ Cf. MALTER, R. Arthur Schopenhauer. Transzendentalphilosophie und Metaphysik des Willens, p. 270.
} 
Schopenhauer concedeu à fisiologia um papel explicativo muito mais fundamental e abrangente do que havia sido teoricamente e sistematicamente planejado ${ }^{39}$. De todo modo, o mérito incomparável de sua interpretação está no seu esforço em tentar mostrar, de modo extremamente sofisticado, que Schopenhauer jamais abandonou os pressupostos do transcendentalismo e que mesmo sua metafísica da vontade é transcendentalmente concebida. Mas essa interpretação se depara com vários problemas, que analisaremos na sequência.

Para ele, há pelo menos três razões que nos forçam a alocar o sistema de Schopenhauer como um todo ainda no horizonte próprio da filosofia transcendental: A) a primeira delas concerne ao ponto de partida formal da metafísica da vontade, denominado por Malter de "transcendentalismo da autoconsciência"; B) a segunda (e mais importante para o autor) diz respeito a um entendimento de qual seria a intenção fundamental da filosofia schopenhauriana em seu conjunto e de como essa intenção se realiza no seu sistema; C) a terceira (que pode ser vista como um desdobramento da segunda) remete à apropriação feita por Schopenhauer da teoria platônica das ideias, que Malter qualifica como um "transcendentalismo da essência"40.

\section{IV.A. O "transcendentalismo da autoconsciência"}

A primeira razão mencinada acima que justificaria uma interpretação transcendentalista da metafísica da vontade é que, na medida em que tem seu ponto de partida num ato de apreensão de uma dinâmica volitiva interna, essa metafísica seria fundada num tipo de autoconsciência e estaria marcada desde o início pela forma do sentido interno, o tempo. Como vimos anteriormente, a dimensão volitiva essencial de nosso próprio eu se apresenta a nós através dos movimentos do corpo e dos sentimentos de dor e prazer, que só se tornam presentes à nossa consciência como fenômenos sucessivos. Ora, a determinação temporal imanente a essa percepção interna representa uma forma rudimentar do princípio de razão, sendo unicamente através dela que esse ato assume um caráter propriamente cognitivo ${ }^{41}$. Apesar de estarem ausentes aqui todas

\footnotetext{
${ }^{39}$ Ibid., p. 269 (nota 3).

${ }^{40}$ Essas razões não são apresentadas pelo autor segundo essa divisão e essa sequência. Trata-se aqui de uma apresentação esquemática segundo a leitura que fazemos de suas teses.

${ }^{41}$ Cf. MALTER, R. Arthur Schopenhauer. Transzendentalphilosophie und Metaphysik des Willens, p. 202.
} 
as outras determinações relativas às formas do espaço e da causalidade, o tempo continua sendo uma condição de possibilidade incontornável dessa experiência particular de manifestação da vontade no próprio eu. A temporalidade é, portanto, a marca do transcendentalismo da autoconsciência.

Contudo, ao tornar possível a construção de uma metafísica essencialista com uma base transcendentalista, a teoria da autoconsciência atribuída por Malter a Schopenhauer se depara com uma enorme dificuldade no tocante à articulação dos predicados da vontade em oposição aos predicados da representação. Já abordamos esse problema por um outro ângulo quando falávamos da equivocidade no uso do termo "vontade" por Schopenhauer. Na ocasião, discutíamos a incongruência entre a experiência que temos da vontade em nossa vida psíquica, na qual a vontade é marcada por aspectos intencionais-cognitivos, e o sentido metafísico-transpessoal do conceito, que exige que a vontade seja pensada como absolutamente alheia a qualquer propriedade cognitiva. O que está em questão agora é a incongruência entre a experiência temporal da vontade na autoconsciência e a exigência metafísica de total atemporalidade da vontade enquanto tal. $\mathrm{Na}$ verdade, de um ponto de vista fenomenológico-transcendental, essas duas questões (relativas ao aspecto cognitivo e ao aspecto temporal respectivamente) são inseparáveis. Como o próprio Malter reconhece, o fato de que a percepção interna da vontade só possa ocorrer sob a forma do tempo constitui um problema crucial para a tese da total alteridade da volição com relação à cognição ${ }^{42}$. De acordo com os pressupostos do idealismo transcendental (isto é, segundo uma fenomenologia transcendental da cognição), o tempo é uma forma própria à cognição, que determina todos os modos possíveis da apreensão intuitiva. Se os atos volitivos se dão segundo uma determinação temporal, deve-se concluir que existe um aspecto cognitivo aí presente.

Ora, a consequência mais imediata da constatação dessa desarmonia entre os atributos da vontade tal como a experienciamos na perspectiva de primeira pessoa, por um lado, e os predicados que somos teoricamente obrigados a atribuir-lhe enquanto entidade metafísica transpessoal, por outro, é a suspeita de que o projeto de uma metafísica imanente nos moldes de Schopenhauer está fadado ao fracasso. E isso porque a vontade que se apresenta temporalmente à percepção interna não pode ser a coisa em

\footnotetext{
${ }^{42}$ Ibid., p. 207.
} 


\section{WILLIAM MATTIOLI}

si. Em última instância, se entendida como absolutamente alheia ao tempo e à cognição, a essência do mundo permanece oculta, inacessível em seu "em si” mais íntimo. Não é de se espantar, portanto, se vemos Schopenhauer vacilar entre afirmações categóricas (presentes sobretudo no livro II do primeiro volume do Mundo), que sustentam a legitimidade plena da experiência interna como meio de acesso à coisa em si enquanto tal, e declarações mais modestas e críticas (presentes sobretudo no segundo volume da obra), que admitem o caráter em certa medida inconclusivo dessa experiência com relação à verdadeira essência do mundo. Malter reconhece a dificuldade, mas opta por atenua-la e em certa medida preteri-la em favor da intuição filosófica de Schopenhauer: apesar de sua inadequação enquanto mediadora do acesso à essência, a percepção interna ainda nos asseguraria um conhecimento legítimo desta ${ }^{43}$.

Essa nos parece ser uma opção interpretativa um tanto quanto comprometida. Ela faz parte do esforço sistemático de Malter em salvaguardar o caráter transcendental da filosofia de Schopenhauer sem com isso ameaçar sua dimensão metafísica (juntamente com seus complementos científico-naturalistas). Porém, a partir de um ponto de vista menos oneroso, poderíamos dizer que, ao estabelecer um dualismo metafísico rígido entre vontade e representação, Schopenhauer impossibilita que a experiência temporal e cognitiva da vontade na perspectiva de primeira pessoa nos forneça um conhecimento válido do "em si” transpessoal do mundo.

Ademais, o argumento de Malter que pretende apresentar uma fundamentação transcendental da metafísica da vontade através de um apelo à autoconsciência como seu momento fundante não é inteiramente convincente. Como afirma Gardner ${ }^{44}$, não devemos nos deixar enganar pelo fato de que Schopenhauer parte de um tipo de experiência de si enquanto vontade, para então afirmar o caráter essencialmente volitivo do mundo enquanto tal. A autoconsciência é, aqui, meramente e trivialmente uma condição para o conhecimento da vontade na perspectiva de primeira pessoa. Em sua explicação do mundo, Schopenhauer apela a algo que é dado cognitivamente nessa perspectiva, mas, como vimos mais acima, ele jamais pretendeu elevar a autoconsciência enquanto tal ao estatuto de instância última legitimadora do conhecimento. Suas teses acerca do inconsciente, do caráter ilusório do "eu" e da natureza instrumental do intelecto o colocam, antes, no lado oposto a esta tendência

\footnotetext{
${ }^{43}$ Ibid., p. 210.

${ }^{44}$ Cf. GARDNER, S. Schopenhauer, Will, and the Unconscious, p. 395s. e p. 417 (nota 90).
} 
hegemônica da filosofia da consciência. Diferentemente de Kant, por exemplo, que identifica a autoconsciência à faculdade superior do entendimento no ato da apercepção transcendental, Schopenhauer coloca a consciência de si na dimensão de uma vivência, que é "afetiva, profunda [...] e difusa"45, e nesse sentido estranha ao caráter racional próprio aos processos de assimilação cognitiva do mundo exterior.

Os passos ulteriores do argumento de Malter, que apontam para uma perda de relevância da tese do primado da vontade e da natureza instrumental do intelecto frente à doutrina da redenção de Schopenhauer, serão analisados na sequência.

\section{IV.B. A doutrina da redenção}

A segunda razão referida acima que, segundo Malter, justificaria uma interpretação transcendentalista da metafísica de Schopenhauer concerne à compreensão de sua intenção filosófica fundamental. Trata-se aqui de uma leitura de seu sistema como um todo em termos de uma doutrina da redenção. $\mathrm{O}$ argumento de Malter pode ser resumido (um tanto quanto grosseiramente) da seguinte forma: para Schopenhauer, o que dá origem à filosofia é o espanto e a perplexidade frente ao sofrimento e à consciência da morte. Há, assim, uma necessidade metafísica que impulsiona o homem ao conhecimento do mundo com o objetivo de desvelar o significado moral da existência e conceder um sentido metafísico ao sofrimento. Desse modo, a necessidade metafísica não seria produto de um interesse meramente teórico. Uma vez que se orienta pela busca de uma significação moral da existência humana, a atividade filosófica estaria de antemão determinada como uma reflexão eticamente motivada. Através dela seria possível atribuir um sentido à negatividade do sofrimento e alcançar o objetivo ético final que é a supressão do sofrimento. Com isso, a filosofia tem uma origem prática e um fim soteriológico ${ }^{46}$. O significado filosófico que o conhecimento (entendimento e razão) assume dentro desse contexto é muito superior àquele que lhe é atribuído no contexto particular da filosofia da natureza, no interior da qual ele é visto como mero instrumento da vontade. $E$ isso porque a redenção, isto é, a libertação do sofrimento pela negação da vontade, só é possível por seu intermédio: a redenção pelo

\footnotetext{
${ }^{45}$ GÖDDE, G. Traditionslinien des „Unbewussten“. Schopenhauer - Nietzsche - Freud, p. 418.

46 Cf. MALTER, R. Arthur Schopenhauer. Transzendentalphilosophie und Metaphysik des Willens, pp. $18-21$.
} 


\section{WILLIAM MATTIOLI}

conhecimento é o momento magno onde a essência é suprimida por seu próprio fenômeno ${ }^{47}$. Frente à intenção fundamental da filosofia schopenhauriana, compreendida como doutrina da salvação, a tese do caráter acidental e instrumental do intelecto perde relevo, e o transcendentalismo, elevado a princípio redentor, assume a primeira ordem na hierarquia do sistema.

O recuo da tese do primado da vontade cega frente ao objetivo soteriológico da filosofia de Schopenhauer é o ponto central da argumentação de Malter. O conhecimento é entendido aqui como algo mais primordial, que pode de algum modo suprimir a própria vontade. Que Schopenhauer, contudo, não pode abrir mão da tese do caráter inconsciente e não-cognitivo da vontade, fica claro tão logo constatamos que dessa tese depende sua intuição existencial-filosófica fundamental, qual seja, que a vida é essencialmente sofrimento e que o sofrimento provém da vontade ${ }^{48}$. Caso a vontade comportasse qualidades intencionais, cognitivas e representacionais, o sofrimento não estaria mais metafisicamente fundamentado, pois o caráter de negatividade do mundo provém justamente do fato de que a vontade é um impulso irracional, inconsciente e cego. Que o mundo seja um vale de lágrimas se explica, segundo a tese de Schopenhauer, pelo fato de que "o princípio de seu ser é um princípio sem fundamento (grundlos), a saber, uma cega vontade de vida [...], pois somente uma vontade cega, incapaz de ver, poderia se enredar nas circunstâncias nas quais nos flagramos." 49 Por sua vez, a negação da vontade como caminho para a libertação do sofrimento só se torna necessária na medida em que a vontade é cega e, com isso, engendra o sofrimento. Consequentemente, a soteriologia, enquanto doutrina da redenção da vontade, depende logicamente da tese de seu caráter cego e não-cognitivo, ou seja, do dualismo estrito entre vontade e representação. Segundo o que vimos mais acima, porém, este dualismo metafísico é exatamente o que coloca a filosofia schopenhauriana no horizonte de um realismo não-transcendental. Se estivermos corretos quanto a isso, portanto, de acordo com os pressupostos teóricos mais fundamentais de sua doutrina, a filosofia de Schopenhauer não seria transcendental, pois mesmo a doutrina da redenção pelo conhecimento depende de uma concepção não-transcendentalista da relação entre vontade e representação, de modo que essa concepção é logicamente primitiva em

\footnotetext{
${ }^{47}$ Cf. MALTER, R. Schopenhauers Transzendentalismus, p. 449.

${ }^{48}$ Ibid., p. 450.

${ }^{49}$ SCHOPENHAUER, A. WWV II/MVR II, p. 662. Cf. a esse respeito GARDNER, S. Schopenhauer, Will, and the Unconscious, p. 383.
} 
relação àquela doutrina.

\section{IV.C. O "transcendentalismo da essência"}

Podemos aprofundar ainda mais essa problemática a partir de uma consideração da terceira razão apresentada por Malter como justificativa para uma interpretação transcendentalista da metafísica de Schopenhauer: sua teoria das ideias. Com efeito, a elevação do transcendentalismo a princípio redentor é um movimento teórico que se realiza, em um de seus momentos cruciais, através do que Malter chama de transcendentalismo da essência, que corresponde à doutrina schopenhauriana das ideias, presente no terceiro livro de sua obra principal. Diferentemente do "transcendentalismo do fenômeno", que concerne à abordagem do mundo como representação submetido ao princípio de razão por um lado e à abordagem da autoconsciência por outro, a expressão "transcendentalismo da essência" é utilizada por Malter para se referir à tese schopenhauriana da objetivação mais imediata e adequada da vontade nas ideias. A ideia é, para Schopenhauer, "a única objetidade imediata da vontade". Enquanto tal, ela é necessariamante "algo conhecido" e encerra em si a forma mais geral da representação: o ser-objeto para um sujeito. Contudo, ela não adentrou a forma do princípio de razão que determina o "conhecimento do sujeito como indivíduo" e, assim, ela é, em termos materiais, "a própria coisa em si (das ganze Ding an sich - a coisa em si em sua totalidade)" ${ }^{" 50}$. Segundo Malter, o transcendentalismo da essência "está contido nessa concepção da relação entre vontade e ideia."

O caráter originário e essencial da "representacionalização" (Vorstellungsgewordensein) da vontade que se manifesta na ideia implica que aquela vontade atemporal, inespacial e indeterminada "já é originalmente sujeito, na medida em que - independentemente da determinação do princípio de razão - ela já se põe diante de si mesma como objeto ("ideia")." As ideias só existem na medida em que a vontade se intui a si mesma, e uma vez que elas são eternas, segue-se daí que "a vontade se intui a si mesma desde a eternidade." 52 Para Malter, esse transcendentalismo da essência é o pressuposto mesmo que torna possível o autoconhecimento da vontade no

\footnotetext{
${ }^{50}$ SCHOPENHAUER, A. WWV I/MVR I, § 32, p. 242.

${ }^{51}$ MALTER, R. Schopenhauers Transzendentalismus, p. 452.

${ }^{52}$ Ibid., p. 453.
} 
mundo regido pelo princípio de razão. O fato da vontade conhecer a si mesma nesse nível originário é a própria condição de possibilidade não somente do mundo representacional em geral, mas também da redenção pelo conhecimento: esta só seria possível "se a vontade já for autoconhecimento" 53 .

Se ela já é autoconhecimento, porém, a tese da ausência absoluta de aspectos cognitivos no âmbito vontade vem a baixo. Se o que dissemos na seção anterior é correto, então vem a baixo juntamente com essa tese a necessidade da redenção da vontade, e a metafísica de Schopenhauer se torna assim um tipo de idealismo objetivo, posto que a vontade será entendida como uma instância mental-cognitiva (Geist). Malter reconhece essa dificuldade fundamental, mas opta mais uma vez por atenuá-la em favor do dualismo estabelecido por Schopenhauer desde o início: "que a vontade tenha alcançado na ideia o adequado autoconhecimento significa tão somente: a vontade, que em si e segundo seu significado ("conteúdo" ["Was"]) é não-mental (geistlos), assumiu a forma da representação, sem com isso converter seu "conteúdo" nessa forma." 54

Entretanto, a questão que se coloca aqui é a seguinte: como seria possível, dentro do contexto teórico em questão, que a forma da representação emergisse repentina e espontaneamente a partir de uma dimensão absolutamente nãorepresentacional? A origem da representação permanece, nesse caso, ininteligível. Nos confrontamos aqui com uma aporia: ou a vontade é aquilo mesmo que representa (isto é, que possui em si a capacidade de representação) - nesse caso a necessidade da redenção não é mais metafisicamente fundada e Schopenhauer se converte em um idealista objetivo -, ou não pode haver representação, pois esta jamais poderia ter origem. Tratase da mesma aporia constatada por Nietzsche, como vimos anteriormente. Com efeito, dois anos após o período de composição das notas sobre Schopenhauer discutidas na seção III, encontramos as seguintes declarações de Nietzsche com relação a esta mesma problemática: "Mas de onde [provém] a representação? Eis o enigma. Naturalmente desde o início, ela não pode ter se originado."55

De acordo com essas reflexões, o naturalismo de Schopenhauer, que vê o intelecto como uma função cerebral que surge a partir do desenvolvimento gradual das formações orgânicas, só pode ser legitimado no horizonte do transcendentalismo se o

\footnotetext{
${ }^{53}$ Ibid.

${ }^{54} \mathrm{Ibid}$.

${ }^{55}$ NIETZSCHE, Fragmento 5[80] de 1870, KSA 7, p. 114.
} 
quadro do idealismo subjetivo kantiano for abandonado. $\mathrm{O}$ surgimento de um aparato cognitivo como o cérebro no seio da natureza depende da existência de mecanismos intencionais-representacionais temporalmente determinados atuando inconscientemente no âmbito da vontade e constituindo uma dimensão de objeto (mesmo que precisemos considerar esses mecanismos como extremamente primitivos $)^{56}$. A filosofia da natureza de Schopenhauer, com sua orientação científica, é de fato transcendentalmente concebida, de modo que o transcendentalismo assume a primeira posição na hierarquia do sistema e coloca a seu serviço os resultados das ciências naturais. Mas esse movimento teórico só pode ser realizado de modo consequente se estivermos dispostos a abrir mão daquele dualismo metafísico estrito entre vontade e representação.

\section{Referências bibliográficas}

BARBERA, S. Eine Quelle der frühen Schopenhauer-Kritik Nietzsches. Rudolf Hayms Aufsatz „Arthur Schopenhauer". In: SCHIRMER, A.; SCHMIDT, R. (Hrsg.) Entdecken und Verraten. Zu Leben und Werk Friedrich Nietzsches. Weimar: Verlag Hermann Böhlaus Nachfolger, 1995.

BRANDÃO, E. A concepção de matéria na obra de Schopenhauer. São Paulo: Humanitas, 2008.

GARDNER, S. Schopenhauer, Will, and the Unconscious. In: Janaway, C. (Hrsg.) The Cambridge Companion to Schopenhauer. Cambridge: Cambridge University Press, 1999.

GÖDDE, G. Traditionslinien des „,Unbewußten“. Schopenhauer - Nietzsche - Freud. Gießen: Psychosozial-Verlag, 2009.

JANAWAY, C. Self and World in Schopenhauer's Philosophy. Oxford: Clarendon Press, 1989.

KANT, I. Kritik der reinen Vernunft. Hamburg: Felix Meiner Verlag, 1998.

LANGBEHN, C. Metaphysik der Erfahrung. Zur Grundlegung einer Philosophie der Rechtfertigung beim frühen Nietzsche. Würzburg: Königshausen \& Neumann, 2005.

LOPES, R. Ceticismo e vida contemplativa em Nietzsche. Tese de doutorado. Belo Horizonte: UFMG, 2008.

\footnotetext{
${ }^{56} \mathrm{Cf}$. a esse respeito as instrutivas observações de Schmidt acerca das dificuldades inerentes à explicação do surgimento de uma matéria sensitiva em formas de vida evolutivamente superiores (SCHMIDT, A. Schopenhauer und der Materialismus, p. XXI, em especial nota 67, p. XLII).
} 
MALTER, R. Arthur Schopenhauer. Transzendentalphilosophie und Metaphysik des Willens. Stuttgart - Bad Cannstatt: Frommann-Holzboog, 1991.

1983.

Schopenhauers Transzendentalismus. In: Midwest Studies in Philosophy, 8,

NIETZSCHE, F. Werke. Kritische Gesamtausgabe (KGW). Bd. I/4. Hrsg. v. G. Colli und M. Montinari. Berlin. New York: Walter de Gruyter, 1995.

Sämtliche Werke. Kritische Studienausgabe (KSA). Bd. 7. Hrsg. v. G. Colli und M. Montinari. Berlin: Walter de Gruyter, 1999.

SCHMIDT, A. Schopenhauer und der Materialismus. In: Schopenhauer-Jahrbuch, 58, 1977.

Physiologie und Transzendentalphilosophie bei Schopenhauer. In: Schopenhauer-Jahrbuch, 70, 1989.

SCHOPENHAUER, A. Sämtliche Werke. Hrsg. v. Paul Deussen. München: Piper Verlag, 1911-1926. (Werke auf CD-ROM: Schopenhauer im Kontext).

O mundo como vontade e como representação. Trad. Jair Barboza. São Paulo: Editora Unesp, 2005.

Recebido: $16 / 10 / 13$

Received: 10/16/13

Aprovado: 05/01/14

Approved: 01/05/14 